8 Sison BS, Weiss W. Needle biopsy of the parietal pleura in patients with pleural effusion. BMJ 1962;ii:298-300.

9 Scerbo J, Keltz H, Stone DJ. A prospective study of closed pleural biopsies. JAMA 1971;218:377-80.

10 Collins TR, Sahin SA. Thoracentesis: complications, patient experience and diagnostic value. Chest 1987;91: 817-9.
11 Light RW, Erozan YS, Ball WC. Cells in pleural fluid. Their value in differential diagnosis. Arch Intern Med 1973; 132:854-60.

12 Prakash UBS, Reiman HM. Comparison of needle biopsy with cytologic analysis for the evaluation of pleural effusion: analysis of 414 cases. Mayo Clin Proc 1985; 60:158-64.

\title{
Adventitia
}

\section{Charlie's Club}

The first club of thoracic surgeons was founded by George Mason of Newcastle upon Tyne. It was called Brown's Club because they met in the hotel of that name in Mayfair. Almost all the thoracic surgeons in the country were members. There were not many of them in 1948-I remember that the meeting of the association took place in a ward in the London Chest Hospital just after I got there in November 1948, and there were about 15 members there. Now, of course, there are 10 times as many.

Charlie's Club was set up about six months after Brown's Club at the London Chest Hospital. Fifteen newly appointed consultants met and agreed that they should meet once a year behind closed doors and report to each other the two most ghastly errors that they had made during the previous year. There is no doubt that the spiritual father of this club was Sir Clement Price Thomas ("Pricie" to us all). He was the most formidably honest surgeon I have ever met-and I have known a lot of them, notably among the members of our club.

I must now digress. Perhaps the accolade for honesty should go to my revered colleague Vernon C Thompson. In the early 1950s he was to go to Oxford to report to the British Thoracic Association a series of 300 thoracoplasties that had been done at the country branch of the London Chest Hospital at Arlesey without any deaths. At that time a 5\% mortality rate was respectable. He met me in the corridor and said, "They will not believe this-I will make it 250 cases." I believe he did. I was much afraid, having been recently appointed to the staff, that I might be responsible for the ending of this quite remarkable series. In fact I was not. The number eventually reached 347 before an unfortunate senior registrar spoiled the record.

It was I who perpetrated the original "Charlie" and published it. I was doing my first solo lobectomy. It was my second lobectomy! Training was not the same in the late 1940 s as it is now. I was intending to take out the left lower lobe and "inadvertently" divided the left main bronchus. I reanastomosed it and all went well. Having just been promoted from being Pricie's RSO, I was in the Brompton shortly afterwards. I told him what had happened. His reaction was, "Well done, my boy." The next day I confessed to my dear chief, Sir Thomas Holmes Sellors, who was known to the whole society as "Uncle Tom." He said, "Oh dear." He was perhaps the greatest delegator of all time and almost certainly the best technical surgeon of his era. I worked for and with him for nearly 30 years and we never had a cross word. I shall never forget the dinner which was held at the Apothecaries Hall, to which all his ex-senior registrars had been invited (and most of them came or sent messages) when he got his knighthood. Every one of them, totally unprompted, got up and spoke with the affection which he richly deserved.

During the 30 years the club remained largely in operation the level of reporting of errors was maintained, as its diary shows. Six of the 18 members became presidents of the Thoracic and Cardiac Surgeons' Association and one became the president of the Royal College of Surgeons of Ireland. Two of them also were presidents of the Thoracic Society.

We pooled statistics and it was the custom that the president for the year wrote the paper. The last one was in 1983, when we collected the follow up for operations on 8781 patients with bronchial carcinoma. But for one or two backsliders it would have been 10000 .

Lastly, in the anecdotal vein, I have a wonderful story about my third dear colleague at the London Chest Hospital - Donald Barlow. He showed a film at our annual meeting one year; he was passing an oesophagoscope down his own oesophagus like a sword swallower. I congratulated him about this film and said, "Donald, you must have had a great deal of practice at this." He replied, "You must think I'm crazy. I did it only once, just for the film." Few people would believe this story, but those who knew him would have no difficulty in doing so.-JACK R BELCHER 